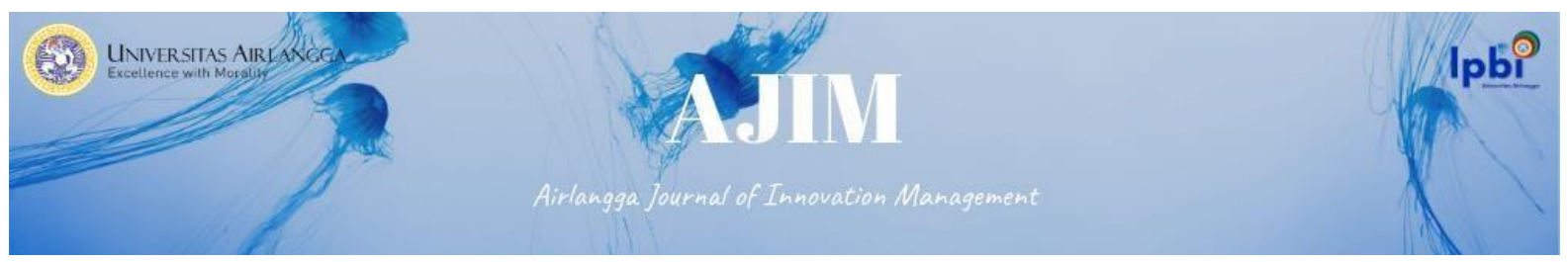

Vol. 2 No.1 Juni 2021

e-ISSN: 2722-5062

DOI : 10.20473/ajim.vvii.26224

\title{
THE INFLUENCE OF GENERATION Z PERCEPTION OF COUNTERFEIT PRODUCT ATTRIBUTE TOWARD PURCHASE INTENTION
}

\author{
Distiani Fitria Kusuma \\ Airlangga University, Surabaya, Indonesia \\ Corresponding e-mail : distiani.kusuma90@gmail.com
}

\begin{abstract}
This research was conducted on $133 \mathrm{z}$ generations of Indonesia. This study uses the Stimulus-OrganismRespondent model to explain counterfeit products' purchase intention in Generation $\mathrm{z}$ in Indonesia. This study uses SEM to analyze research results. This study's results indicate that the stimulus of past experience, product knowledge, product appearance, novelty-seeking, status consumption, and information susceptibility can affect the utilitarian and hedonic attitude of generation $\mathrm{z}$ towards imitation products. The utilitarian and hedonic attitudes of generation $\mathrm{Z}$ affect the counterfeit product purchase intention. These results can understand what stimuli can affect generation Z's attitude towards counterfeit products and how this affects the counterfeit product purchase intention.
\end{abstract}

Keywords: Stimulus-Organism-Respond, S-O-R, Purchase Intention, Counterfeit Product, Generation z

\section{Introduction.}

Globalization brings changes to the lifestyle of the Indonesian people. The entry of globalization to Indonesia has made it easier for Indonesians to access foreign products or brands. Indonesian people find it easier to get high fashion products to fast fashion. Several leading brands such as Louis Vuitton, Gucci, Hermes, Prada, Kate and Spade, Supreme, Channel, Ralph Lauren to Zara, UNIQLO, H\&M, Bershka are now easily found in shopping center outlets in Indonesia. The increasing number of luxury products creates a distinct consumption pattern in Indonesian society.

Generation $\mathrm{z}$ is a generation born after generation y (millennial), born between 1995 and 2010 (Bencsik, Csikos and Juhez, 2016). Generation $z$ has a different consumption pattern from the previous generation. Arda and Andriany (2019) state that generation $z$ has a very high level of consumption. It is effortless to make purchases. Generation $\mathrm{Z}$ tends not to think about the usefulness of the products they buy, so they easily make purchases for products that are not needed or even needed.

Sabanoglu (2020) states that Generation $\mathrm{Z}$ is responsible for 32 percent of luxury products' sales on the market. This figure is predicted to increase by 45 percent in 2025. Jain, Vatsa, and Jani (2014) add that generation $\mathrm{z}$ is a generation that is aware of high fashion products and the need for luxury products. In Indonesia, the sales of luxury products have increased by 84 percent, making Indonesia as country with an enormous sales of luxury products in Asia (Reebonz, 2016). Indonesia itself occupies 


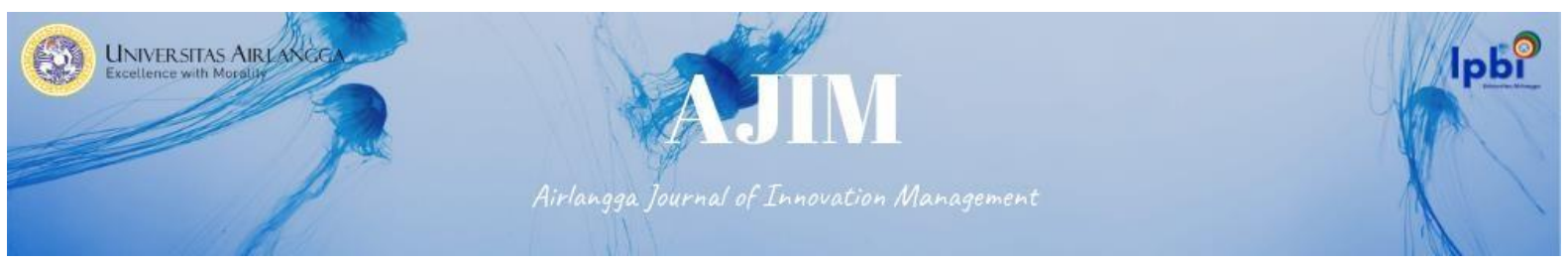

third position as a country with massive consumption of luxury products (Capgemini Asia Pacific, 2015)

Indonesians' high buying interest in certain luxury brands has created market opportunities for luxury goods in Indonesia. The need for luxury goods creates opportunities for producers to meet these needs. This opportunity applies to manufacturers of luxury goods and manufacturers of counterfeit from branded goods. Rachmat Gobel stated that at least 40 percent of Indonesia's market products are counterfeit products or KW (Indonesia surga barang palsu, 2015). Fashion products are the secondhighest counterfeit product (Tempo, 2017). KW products or counterfeits themselves are illegal items that imitate a design of a particular brand or designer. The imitation process starts from details, logo, and even label shape of item (Rath et al., 2015)

The high number of counterfeit products in Indonesia cannot be separated from Indonesian consumers' buying interest. Based on a survey released by INTA (2019), it is stated that 87 percent of $\mathrm{Z}$ generation in Indonesia have bought counterfeit goods or around 3700 people. The survey also added that 5 percent of generation $\mathrm{z}$ would buy more counterfeit products than in previous year. Erna Wahyuningsih (2016) states that there are several reasons why Indonesians often purchase counterfeit or KW products. It includes the quality of kw or imitation products that are almost the same as the original product. The prices are more affordable, easier to find, and follow product trends (Wahyuningsih, 2016). Survey conducted by INTA (2019) also states that reasons why generation z buys counterfeit goods or KW. It includes easy access to counterfeit products, purchasing power, purchasing counterfeit goods will be more acceptable in future, lifestyle or social status is given by brand and experience with fake product.

Moon et al. (2018) stated that consumer buying interest in counterfeit products could be explained using the S-O-R or Stimulus- Organism-and Response model. It is different from Theory of planned behavior and the theory of reasoned action, which only explain buying interest as a consumer cognitive process. Consumers are seen as rational individuals in purchasing a product (Ajzen and Fishbein, 2005). The S-O-R model sees consumers as more complex individuals. A person's buying decision is seen from cognitive structure and side of one's behavior and social psychology (Mehrabian and Russel, 1974; Moon et al., 2018).

Several previous studies have explained an inconsistency between consumer attitudes towards counterfeit or KW products (Moon et al., 2018). Chiu and Leng (2016) stated that attitude of like or dislike of consumers towards counterfeit goods does not necessarily influence consumers' buying interest in counterfeit goods.

Based on explanation above, this study looks at relationship between generation z perceptions of counterfeit products or KW with these goods' purchase intentions. This research is expected to provide an overview of generation z's perceptions of counterfeit goods and their relationship toward counterfeit products' purchase intentions in generation $\mathrm{z}$.

\section{Literature Review}

\section{1) Stimulus - Organism - Response Model}

Mehrabian and Russel (1974) state that environment is a stimulus (S), which consists of a group of signs that cause internal judgments in a person $(\mathrm{O})$ and then form a person's response (R). Mehrabian and Russel (1974) stated that consumer emotions play an essential role in responding to existing stimuli (Mowen, 2002). Donovan (1982) adds that this model also says that a person's conscious perception, 


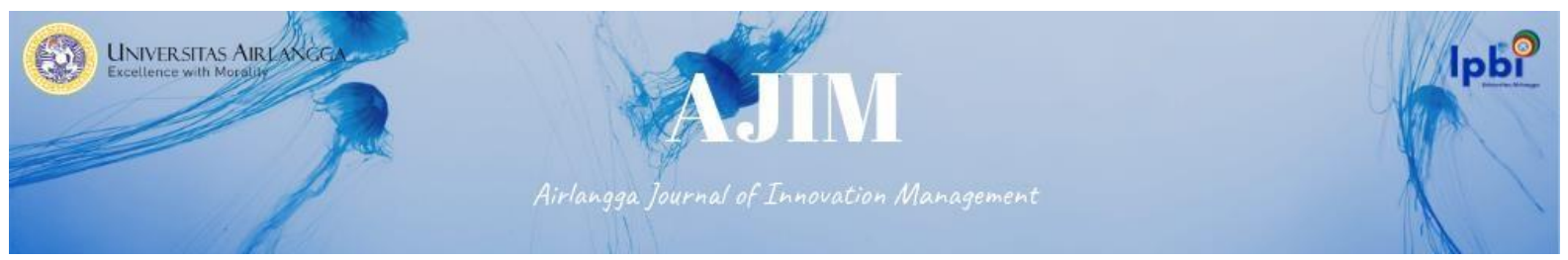

unconscious perception, and interpretation of environment can influence what a person feels. Mehrabian and Russel (1974) state that a person's emotional response can be explained in three dimensions:

a. Pleasure, which can be explained by a person's verbal assessment of environment, where it is shown in the form of fun, happiness, or the level of satisfaction with certain situations

b. Arousal, which can be explained by a broader verbal assessment, in form of individual pleasure and activity in certain situations

c. Dominance can be explained by an indication of a person's feelings, shown by a person's willingness to dominate and influence certain situations.

In this research, stimulus is described as a psychosocial stimulus and object's stimulus (Slama and Taschian, 1987). Slama and Taschian (1987) explain that psychosocial stimulus is related to individual's environment, while object stimulus describes product's characteristics. Consumption and complexity of these products (Moon et al., 2018).

Olson and Jacoby (1972) stated that utilization theory is a theory that can identify an object and psychosocial stimuli. Utilization theory states that consumers will rely on available information before making a purchase and use this information as an attribute to deal with uncertainty of process. Eroglu et al. (2001) and Wang (2017) state that object stimulus is related to cognitive and affective stimuli, while psychosocial stimuli are related to social attributes. Moon et al. (2017) form that cognitive attributes are connected to a product's function and consumers use these attributes as cognitive cues in decision making.

Affective attributes are attributes related to happiness, entertainment, pleasure when purchasing a product (Moon et al., 2018). An Affective attribute can be seen as a consumer's search for new and innovative products regardless of their function. Consumer's instinct will look for pleasure in a product. A product's appearance is considered to be most critical sensory element and most critical stimulus.

Psychosocial attributes are cues taken from community and environment around individual (Salma and Tashchian, 1987). Psychosocial attributes are considered most critical stimulus. Consumers are considered vulnerable to social pressure and attention to image they form in environment (Wang, 2017).

2) Counterfeit Product Intentions

\subsection{Past Experience}

Previous experiences are previous interactions between products and consumers. These interactions have gone through an evaluation process by consumers (Bian et al., 2016). Moon et al. (2018) added that consumers familiar with counterfeit goods know advantages of counterfeit goods offered to them, considering that counterfeit goods are cheaper and can be assessed as an alternative to original products (Pueschel et al. 2017; Moon et al., 2018). Augusto de Matos et al. (2017) stated that previous good experiences with counterfeit products could lead to higher purchase intentions. Moon et al. (2018) noted that counterfeit goods' prior experience was more towards assessing imitation goods' function.

\subsection{Product Knowledge}

Moon et al. (2018) state that product knowledge is consumer ownership of information specific to a particular product or category. Consumers' perceptions of product types can describe variations in consumer knowledge of a product (Laroche and Maxie, 2003). Consumers who have detailed knowledge of a product will evaluate a product and find alternatives compared to consumers who have less knowledge (Moon et al., 2018; Davidson et al., 2017). Moon et al. (2018) stated that the knowledge possessed by a consumer would make consumers understand the function of a product 


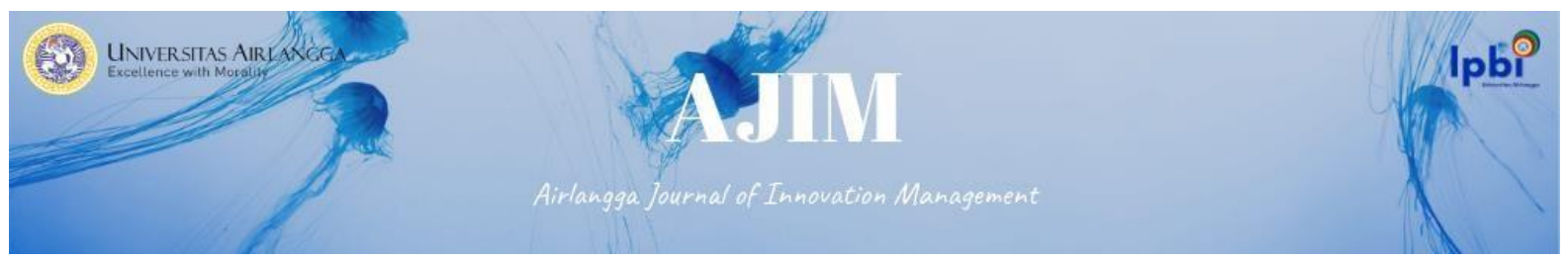

\subsection{Product Appearance}

Physical appearance is a characteristic that can help consumers to assess the aesthetics and symbolic function of a product (Blijlevens et al., 2017; Moon et al., 2018). Similarity in counterfeit products' appearance can provide high emotional value for consumers (Moon et al., 2018). Bian et al. (2016) stated that imitation products usually pay more attention to product's appearance. Consumers will ignore practical use of counterfeit goods if they feel happy with product's aesthetics (Moon et al., 2018). Kim and Karpova (2010) state that counterfeit goods' appearance will be considered a reward for consumers. Davidson et al. (2017) suggest that similarity in appearance between fake and original products will make consumers develop positive emotions towards counterfeit goods.

\subsection{Novelty Seeking}

Novelty seeking is an internal motivation or internal encouragement from consumers to explore new information (Hirchman, 1980). Rishi and Mehra (2017) state that for an imitation product, a unique design and a design according to original product will provide an opportunity for consumers to suppress their desires and try new items. The nature of cheap imitation products and various original branded products will help consumers fulfill their needs to experiment and answer their curiosity (Moon et al., 2018). Wang (2017) states that consumers who enjoy trying new things will be more concerned about fulfilling their internal motivation by experimenting rather than seeing product and benefits of product itself.

\subsection{Status Consumption}

Consumption status is buying behavior, using and consuming a product to get a position in environment (Teah et al., 2015). Individuals with lower incomes will usually show a pleasant attitude towards counterfeit goods (Moon et al., 2018). Consumers who are aware of social status will seek selfindulgence in a product, and they will tend to use products from well-known brands. It will make them experience self-identity and attachment to a specific class (Moon et al., 2018; Eastman and Eastman, 2011). On the other hand, consumers aware of this social status show themselves in environment by discussing characteristics and advantages of a product and getting it at a lower price (Eisen et al., 2017). Counterfeit products provide opportunities for consumers to improve their social status with less expenditure (Moon et al., 2018). Consumers who are aware of their position are usually mindful of their class from counterfeit goods, but they will look for other benefits from imitation products (Moon et al., 2018; Davidson et al., 2017).

\subsection{Susceptibility to Interpersonal Influence}

Susceptibility to Interpersonal Influence is vulnerability of consumers to interpersonal influences (Moon et al., 2018; Rishi and Mehra, 2017). Interpersonal influence consists of two dimensions, namely informational and normative influences (Sharma and Chan, 2017). The effect of information is consumers' tendency to trust other people's information about actual reality (Wang, 2017). Consumers who have little knowledge of product categories will rely on opinions of others. Suppose people, environment, or closest group of individuals have more knowledge about an imitation product (functionally and emotionally). In that case, this will influence individual to have a positive attitude towards counterfeit goods.

Meanwhile, normative influence can be defined as consumers' desire to develop trust and specification as a material for decision-making (Wang, 2017). These consumers will see their immediate environment as a reference group for use of counterfeit products and functional benefits of these products (price, quality, etc.) or emotional benefits (positive self-image), which they form from a 


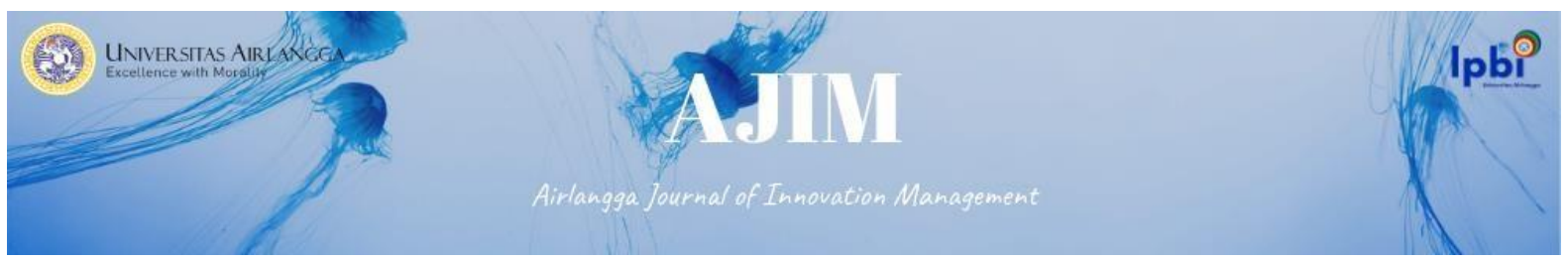

positive attitude towards counterfeit goods (Moon et al., 2018) ). Ajzen and Fishbein (1980) say that consumer acceptance or rejection of purchasing behavior from their immediate environment will cause consumers to be in a depressed position or be forced to align their behavior with their immediate environment.

\subsection{Utilitarian and Hedonic Attitude}

Attitude is described as a pleasant or unpleasant product evaluation (Ajzen and Fishbein, 2005). Eroglu et al. (2001) and Moon et al. (2018) state that self-attitudes are divided into hedonic and utilitarian. Utilitarian attitude is attitude of consumers who emphasize function and evaluation of product's instruments itself (Noh et al., 2014; Moon; et al., 2018). Meanwhile, hedonic attitude is more concerned with happiness, pleasure, or sensory sensations that encourage positive feelings from a product (Wang, 2017). Teah et al. (2015), Amaral and Loken (2016) and Wang, (2017) state that consumer attitudes towards a product will encourage consumer intention to buy product.

\section{Method Sample}

This study uses z generation population in Indonesia. Z generation is a generation born from 1995 to 2010 (Bencsik, Csikos and Juhez, 2016). Maholtra et al. (2017) state that minimum sample used to conduct online research is 100 samples. This study uses a purposive sampling method, where researcher has determined sample criteria that can be used as a sample in this study (Neuman, 2003). In this research, it has been determined that this study used $\mathrm{z}$ generation as a sample.

\section{Measurement}

This study uses a measuring tool adapted from Moon et al. (2018) where there are seven variables described as a stimulus, namely past experience (3 items), product knowledge (3 items), product appearance (3 items), novelty seeking ( 2 items), consumption status ( 2 items), normative susceptibility (3 items), information susceptibility ( 2 items). As for attitude, there are two variables, namely utilitarian attitude ( 2 items) and hedonic attitude ( 3 items), and purchase intentions (4 items) as a response. Each variable has its respective reliability, past experience (.875), product knowledge (.674), product appearance (.929), novelty seeking (.713), status consumption (.705), normative susceptibility (.825), information susceptibility (.791), utilitarian attitude (.819) hedonic attitude (.941), and purchase intentions (.914). All variables are measured using a liker scale ranging from 1 for strongly disagree to 5 for strongly agree.

\section{Data Collection Method}

This research was conducted on 133 subjects, with 103 female, 25 male, and 5 of them did not answer. Subjects in this study were z generation who were born between 1996 and 2010. Subjects in this study 121 of them had bought counterfeit products, and 12 of them had not. Most of subjects in this study stated that they would not purchase counterfeit products in future (84 people), and some other people might buy counterfeit products (40 people). One hundred one subjects in this study were students, 5 of whom were civil servants, 17 were private employees, 4 were entrepreneurs, and 6 had jobs outside options that had been provided. Income in subjects in this study was obtained from parents' pocket money ( 95 people); 32 people came from salaries, six people came from other income. Income or allowances for subjects of this study ranged from 500,000 to $1,000,000$. 

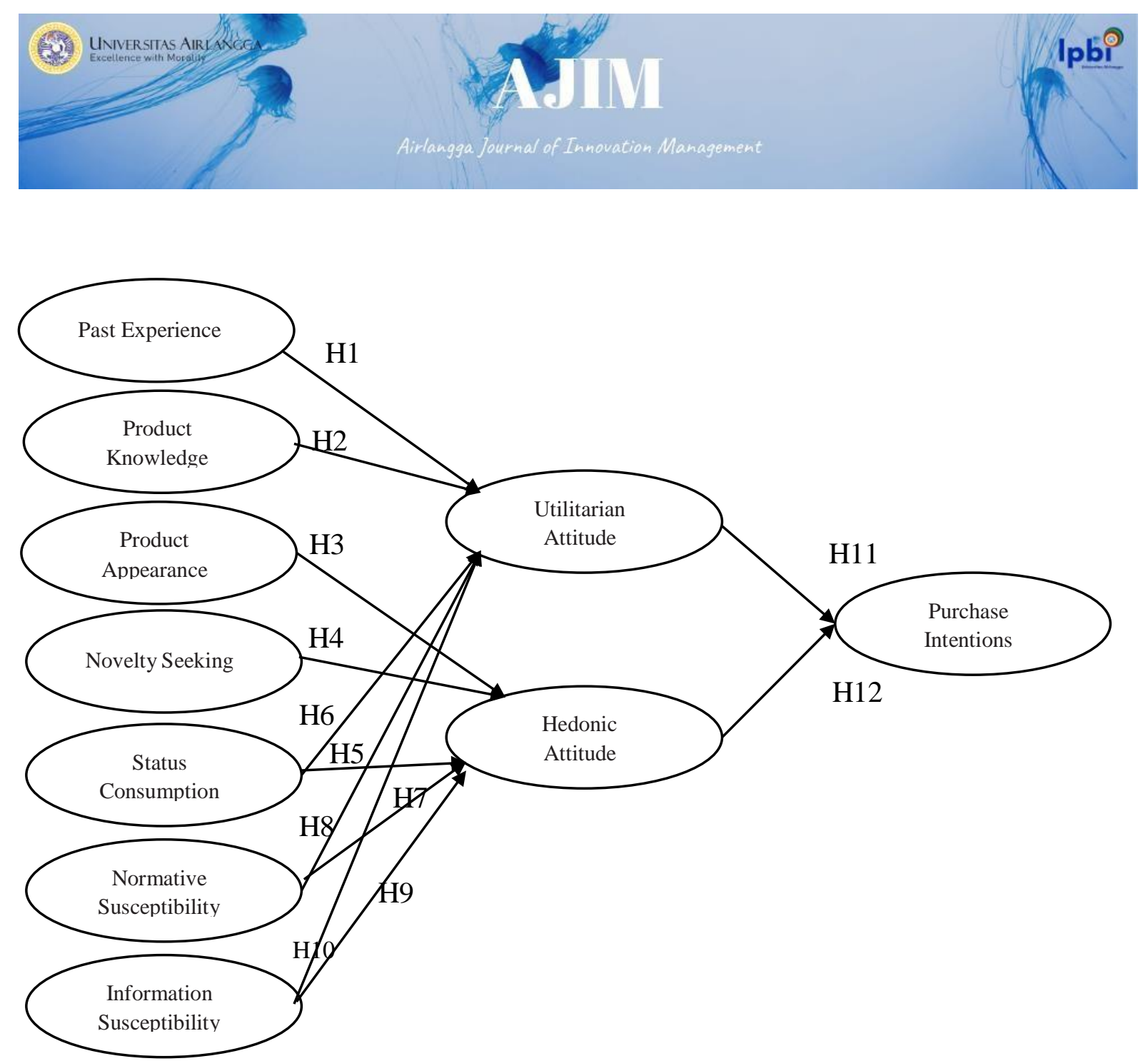

Source: Research result (2021)

Figure 1. Conceptual Figure

\section{Data Analysis Procedure}

This study uses SEM at AMOS 26 to analyze effect of each variable

\section{Result and Discussion}

ctive pilgrims. Then, SPPH sheet is stamped and one sheet is given with portion number for prospective hajj pilgrims and four sheets for data at Ministry of Religion.

This study states that only past experience (p .000) and product knowledge (p .000) variables can influence utilitarian attitude. Both of these variables have a positive effect on utilitarian attitudes. While status of consumption (p.135), normative susceptibility (p.266), and information susceptibility (p. 099) did not affect utilitarian attitude ( $p>.05$ ). In hedonic consumption variable, variable product appearance ( $\mathrm{p} .000$ ), novelty seeking ( $\mathrm{p} .000$ ), status consumption ( $\mathrm{p} .000$ ), and information susceptibility (p .031) affect hedonic consumption. Variable product appearance, novelty-seeking, and consumption status positively affect hedonic attitude, while information susceptibility has a negative effect on hedonic attitude. However, normative attitude (p.218) in this study is known not to affect hedonic attitude. This study also states that utilitarian attitude and hedonic consumption affect purchase intentions $(\mathrm{p}<.05)$. 


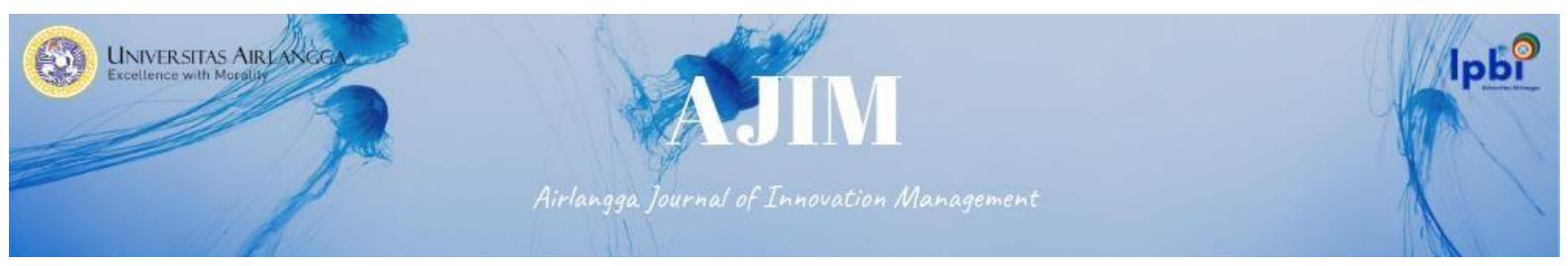

Table 1. Hypothesis Test Result

\begin{tabular}{clrrl}
\hline Hypotesis & \multicolumn{1}{c}{ Path } & \multicolumn{1}{c}{$\boldsymbol{\Gamma}$} & p-values & Conclusion \\
\hline H1 & Past experience $\rightarrow$ Utilitarian attitude & 0.31 & 0.00 & Accepted \\
\hline H2 & Product knowledge $\rightarrow$ Utilitarian attitude & 0.35 & 0.00 & Accepted \\
\hline H3 & Product appearance $\rightarrow$ Hedonic attitude & 0.25 & 0.00 & Accepted \\
\hline H4 & Novelty seeking $\rightarrow$ Hedonic attitude & 0.67 & 0.00 & Accepted \\
\hline H5 & Status consumption $\rightarrow$ Hedonic attitude & 0.39 & 0.00 & Accepted \\
\hline H6 & Status consumption $\rightarrow$ Utilitarian attitude & 0.08 & 0.13 & Denied \\
\hline H7 & Normative susceptibility $\rightarrow$ Hedonic attitude & -0.08 & 0.00 & Accepted \\
\hline H8 & Normative susceptibility $\rightarrow$ Utilitarian attitude & -0.46 & 0.26 & Denied \\
\hline H9 & Information susceptibility $\rightarrow$ Hedonic attitude & -0.17 & 0.03 & Accepted \\
\hline H10 & Information susceptibility $\rightarrow$ Utilitarian attitude & -0.90 & 0.09 & Denied \\
\hline H11 & Utilitarian attitude $\rightarrow$ Purchase intention & 0.65 & 0.00 & Accepted \\
\hline H12 & Hedonic attitude $\rightarrow$ Purchase intention & 0.47 & 0.00 & Accepted \\
\hline R
\end{tabular}

Source: Research result (2021)

Based on results of this study, it is known that past experience and product knowledge have a positive effect on attitude utility. This is in line with previous research conducted by Chen et al. (2020), Moon et al. (2018), Kim and Karpova (2010), and Bian et al. (2016). Chen et al. (2020) state that consumers' past experiences with a product will affect utilitarian attitude of consumers towards a product. Past consumer experience of a product will bring a consumer understanding of a product. Kim and Karpova (2010) also added that individuals who have had positive experiences with counterfeit products and have strong product knowledge about these imitation products would form a positive behavior towards imitation products.

As for consumption status, normative susceptibility and information susceptibility do not affect utilitarian attitude. Eng and Bogaert (2010) state that consumption status will not affect utilitarian attitude. Moon et al. (2018) also added that informative susceptibility would not affect utilitarian attitude. Moon et al. (2018) add that consumers will not risk investing in counterfeit goods only because consumer's immediate environment is using these goods. These results are in line with characteristics of Z generation. Francis and Hoefel (2018), in their article entitled 'True Gen: Z Generation and its implication for companies', try to explain traits possessed by $\mathrm{Z}$ generation. $\mathrm{Z}$ generation consumers have a high awareness of value of individuality. Generation $z$ consumers value importance of individual expressions more. $\mathrm{Z}$ generation will also avoid labeling itself more. $\mathrm{Z}$ generation also looks more at comfort and style regardless of whether item is branded or not. $Z$ generation also values quality of a product more. Counterfeit goods are not necessarily of comparable quality to original product. The nature of $\mathrm{z}$ generation that loves a brand as work is one reason why $\mathrm{z}$ generation does not see goods through function of product itself.

For hedonic attitude, product appearance variables, novelty-seeking, and consumption status positively affect hedonic attitude, while information susceptibility has a negative effect on hedonic attitude. The positive impact of product appearance, novelty-seeking, consumption status on hedonic attitude is in line with Moon et al. (2018). It is undeniable that nature of product appearance, noveltyseeking of counterfeit products, affects generation $\mathrm{z}$ consumers' hedonic attitude. $\mathrm{Z}$ generation tends to see products from its model, so that $\mathrm{z}$ generation will see product more from its appearance and nature of $\mathrm{z}$ generation, who likes to try new things. It will encourage $\mathrm{z}$ generation to buy or try new products. 


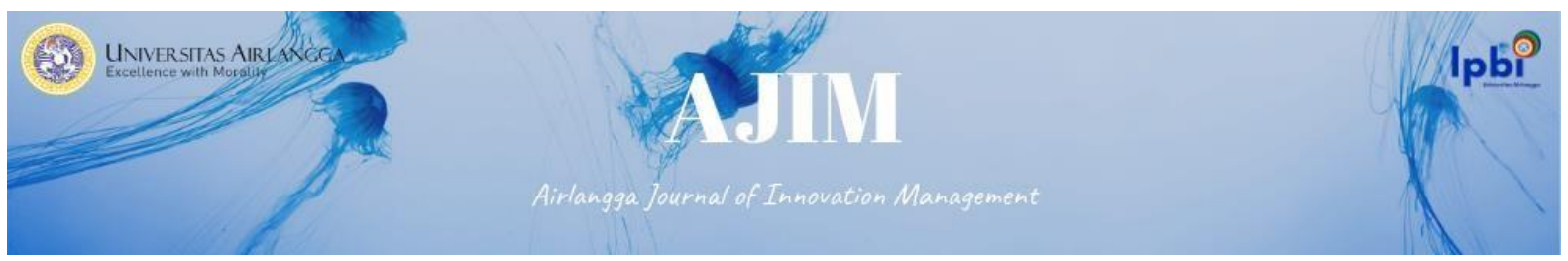

But not for information susceptibility and normative susceptibility. Information susceptibility has a negative effect on hedonic attitude in z generation. It in line with research conducted by Phau and Teah (2009). Information susceptibility is consumers' tendency to trust information obtained from other people about actual reality (Wang, 2017). Z generation is a technology-literate generation. Z generation will not easily believe information provided by others. $Z$ generation will tend to seek information about a product (Estrella, 2020). Therefore, with convenience it has, $z$ generation will manage to avoid buying counterfeit products. $\mathrm{Z}$ generation is also more concerned with value of individuality. Therefore normative susceptibility or tendency of individuals to see their immediate environment as a reference group for counterfeit products and functional advantages of a product do not affect hedonic attitude in $\mathrm{z}$ generation.

In this study, it was also found that utilitarian and hedonic attitudes affected purchase intentions of counterfeit goods, where utilitarian attitude had a more significant effect than hedonic attitude. It in line with research conducted by Ting et al. (2016) and Chiu and Leng (2016), nature of z generation, which is more concerned with convenience of a product, causes z generation not to see whether product is an imitation or a branded product.

\section{Conclusion}

Based on this study's results, it was found that consumer attitudes towards a counterfeit product can influence purchase intentions. Attitude is also influenced by several stimuli such as past experience, product knowledge, product appearance, novelty-seeking, status consumption, information susceptibility but not for normative susceptibility variables. Different nature of $\mathrm{z}$ generation from previous generations brings a different attitude towards counterfeit products, where it will also bring differences to purchase counterfeit products intentions. Understanding characteristics possessed by z generation will understand what stimuli can form z's generation attitude towards a product.

\section{Reference}

Ajzen, I. and Fishbein, M. (2005), "The influence of attitudes on behavior", The Handbook of Attitudes, 173(221), 173-221

Amaral, N.B. and Loken, B. (2016), "Viewing usage of counterfeit luxury goods: social identity and social hierarchy effects on dilution and enhancement of genuine luxury brands", Journal of Consumer Psychology, Vol. 26 No. 4, pp. 483-495.

Arda, Mutia; Amdriany, Dewi. (2019). Analisis Faktor Stimuli Pemasaran Dalam Keputusan Pembelian Online Produk Fashion Pada Generasi Z. Jurnal INTEKNA, 19(2), 69-133.

Augusto de Matos, C., Trindade Ituassu, C. and Vargas Rossi, C.A. (2007), "Consumer attitudes toward counterfeits: a review and extension", Journal of Consumer Marketing, Vol. 24 No. 1, pp. 3647.

Bencsik, A., Csikos, G., \& Juhaz, T. (2016). Y and Z Generations at Workplaces. Journal of Competitiveness, 8(3), 90-106

Bian, X., Wang, K.Y., Smith, A. and Yannopoulou, N. (2016), "New insights into unethical counterfeit consumption", Journal of Business Research, Vol. 69 No. 10, pp. 4249-4258.

Blijlevens, J., Thurgood, C., Hekkert, P., Chen, L.L., Leder, H. and Whitfield, T.W. (2017), "The Aesthetic pleasure in design scale: the development of a scale to measure aesthetic pleasure for designed artifacts", Psychology of Aesthetics, Creativity, and the Arts, Vol. 11 No. 1, pp. 8698. 


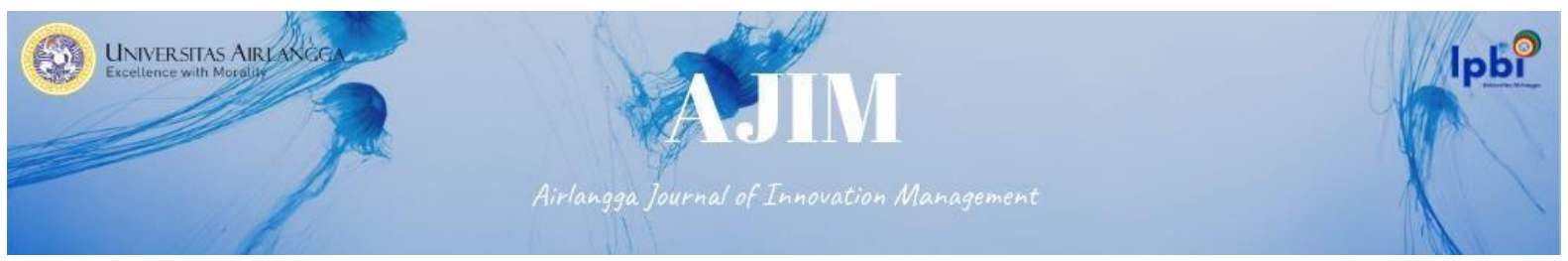

Capgemini Asia Pasific. (2015). AsiaPacific Wealth Report 2015. Available at:: https://www.worldwealthreport .com/apwr

Chiu, W. and Leng, H.K. (2016), "Consumers' intention to purchase counterfeit sporting goods in Singapore and Taiwan", Asia Pacific Journal of Marketing and Logistics, 28(1), 23-36.

Davidson, A., Nepomuceno, M.V. and Laroche, M. (2017), "Shame on you: when Materialism leads to purchase intentions toward counterfeit products", Journal of Business Ethics, pp. 1-16, available at: https://doi.org/10.1007/s10551-017-3565-8

Eastman, J.K. and Eastman, K.L. (2011), "Perceptions of status consumption and the economy", Journal of Business \& Economics Research, Vol. 9 No. 7, pp. 9-19.

Eisend, M., Hartmann, P. and Apaolaza, V. (2017), "Who buys counterfeit luxury Brands? A metaanalytic synthesis of consumers in developing and developed markets", Journal of International Marketing, Vol. 25 No. 4, pp. 89-111.

Eng, T-Y, Bogaert, J. (2010), Psychological and Cultural Insights Into Consumption of Luxury Western Brands in India, Journal of Customer Behaviour, Vol. 9 No. 1, pp. 55-75

Eroglu, S.A., Machleit, K.A. and Davis, L.M. (2001), "Atmospheric qualities of online retailing: a conceptual model and implications", Journal of Business Research, Vol. 54 No. 2, pp. 177-184.

Estrella, Kris. (2020). The Defining Characteristics Of Generation z. available at: https://extremereach.com/blog/the-defining-characteristics-of-generation-z/

Francis, Taylor; Hoefel, Ferananda. (2018). True Gen: Generation Z and Its implications for companies. Available at: https://www.mckinsey.com/industries/consumer-packaged-goods/ourinsights/true-gen-generation-z-and-its-implications-for-companies

Hetharie, Jondry Adrin; Surachman; Hussein, Ananda Sabil; Puspaningrum; Astrid. (2019). SOR (Stimulus-Oganism-Response) Model Application In Observing The Influence Of Impulsive Buying O Consumer's Post-Purchase Regret. International Journal Of Scientific \& Technology Research. 8(11).

Hirschman, E.C. (1980), "Innovativeness, novelty seeking, and consumer creativity", Journal of Consumer Research, Vol. 7 No. 3, pp. 283-295.

INTA. (2019). Wawasan Generasi Z: Merek dan Produk Tiruan. Available at:: https://www.inta.org/wp-content/uploads/public-files/perspectives/industry-research/BahasaIndonesia_Gen-Z-Insights-Global.pdf

Jain, Varsha; Vatsa, Reshma; Jagami, Khyati. (2014). Exploring Generation Z's Purchase Behavior toward Luxury Apparel: a Conceptual Framework. Romanian Journal of Marketing. Vol.2, 18 29

Kim, H. and Karpova, E. (2010), "Consumer attitudes toward fashion counterfeits: application of the theory of planned behavior", Clothing and Textiles Research Journal, Vol. 28 No. 2, pp. 79-94.

Laroche, M.J. and Maxie, A. (2003), "Ten considerations in addressing cultural differences in psychotherapy", Professional Psychology Research and Practice, Vol. 34 No. 2, pp. 180-186.

Maholtra, Naresh K; Nunan, Daniel' Birks, David F. (2017). Marketing Research: An Applied Approach(5th Edition). UK: Pearson.

Mehrabian, A. and Russell, J.A. (1974), An Approach to Environmental Psychology, MIT Press, Cambridge, MA

Merdeka.com (2015). Indonesia Surga Barang Palsu. Available at:: https://www.merdeka.com/uang/indonesia-surga-barang-palsu.html 


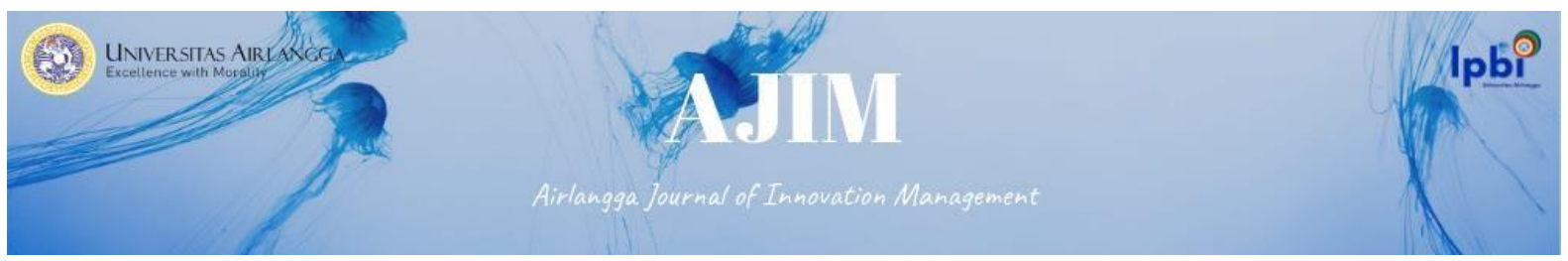

Moon, Ahmad Moin; Javaid, Batish; Kiran, Maira; Awan, Hayat Muhammad; Farooq, Amna. (2018). Consumer perceptions of counterfeit clothing and apparel products attributes. Marketing Intelligence \& Planning

Mowen, J. C. and Michael Minor. 2002. Perilaku Konsumen. Penerbit: Erlangga, Jakarta

Neuman, W Lawrence. (2006). Social Research Methods: Qualitative and Quantitative Approach (5th Edition). Toronto: Pearson

Noh, M., Runyan, R. and Mosier, J. (2014), "Young consumers' innovativeness and hedonic/utilitarian cool attitudes", International Journal of Retail \& Distribution Management, Vol. 42 No. 4, pp. 267-280.

Olson, J.C. and Jacoby, J. (1972), "Cue utilization in the quality perception process", in Venkatesan, M. (Ed.), SV - Proceedings of the Third Annual Conference of the Association for Consumer Research, Association for Consumer Research, Chicago, IL, pp. 167-179, Available at: : http:// acrwebsite.org/volumes/11997/volumes/sv02/SV-02

Phau, L., \& Teah, M. (2009). Devil wears (counterfeit) Prada: A Study of Antecedents and Outcomes of Attitudes Towards Counterfeit. Of Luxury Brand. Journal Of Marketing. 26(1). 15-27.

Pueschel, J., Chamaret, C. and Parguel, B. (2017), "Coping with copies: the influence of risk perceptions in luxury counterfeit consumption in GCC countries", Journal of Business Research, Vol. 77, pp. 184-194, available at: https://doi.org/10.1016/j.jbusres.2016.11.008

Rath, Patricia; Bay, Stefani; Petrizzi, Richard; Gill, Penny. (2015). The Why of The Buy. New York: Fairchild Books, Inc.

Reebonz. (2006). Asia Luxury Index 2016.. Available at:: http://cdn3.reebonz.com/SG/static/ReebonzAsia-Luxury-Index-2016-HighRes.pdf

Rishi, B. and Mehra, A.K. (2017), "Key determinants for purchasing pirated software among students", International Journal of Technology Marketing, Vol. 12 No. 1, pp. 4-22.

Sabanoglu, Tugba. (2020). Gen Y and Z Share of Global Personal Luxury. Good Market in 2017 and 2025.

Sharma, P. and Chan, R.Y. (2017), "Exploring the role of attitudinal functions in counterfeit purchase behavior via an extended conceptual framework", Psychology \& Marketing, Vol. 34 No. 3, pp. 294-308.

Slama, M.E. and Tashchian, A. (1987), "Validating the SOR paradigm for consumer involvement with a convenience good", Journal of the Academy of Marketing Science, Vol. 15 No. 1, pp. 36-45.

Teah, M., Phau, I. and Huang, Y.A. (2015), "Devil continues to wear 'counterfeit' Prada: a tale of two cities", Journal of Consumer Marketing, Vol. 32 No. 3, pp. 176-189.

Tempo.co. (2017). Berikut daftar barang palsu tertinggi di Indonesia. Available at:: https://bisnis.tempo.co/read/848463/berikut-daftar-barang-palsu-tertinggi-diindonesia/full\&view $=$ ok

Ting, M.S., Goh, Y.N. and Isa, S.M. (2016), "Determining consumer purchase intentions toward counterfeit luxury goods in Malaysia", Asia Pacific Management Review, Vol. 21 No. 4, pp. 219-230.

Wahyuningsih, Erna. (2016). Mengapa Orang Suka Produk Imitasi. Available at:: https://dosen.perbanas.id/mengapa-orang-suka-produk-imitasi.html

Wang, E.S.T. (2017), "Different effects of utilitarian and hedonic benefits of retail food packaging on perceived product quality and purchase intention", Journal of Food Products Marketing, Vol. 23 No. 3, pp. 239-250. 